\begin{tabular}{r|l|l|l}
$\begin{array}{c}\text { Case Reports in } \\
\text { Gastroenterology }\end{array}$ & $\begin{array}{l}\text { Case Rep Gastroenterol 2010;4:313-317 } \\
\text { DOl: 10.1159/000320672 }\end{array}$ & $\begin{array}{l}\text { Published online: } \\
\text { September 9, 2010 }\end{array}$ & $\begin{array}{l}\text { O 2010 S. Karger AG, Basel } \\
\text { ISSN 1662-0631 } \\
\text { www.karger.com/crg }\end{array}$ \\
\hline
\end{tabular}

\title{
Cavernous Transformation of the Portal Vein Might Increase the Risk of Liver Abscess
}

\author{
Xin-Bo Ai ${ }^{\mathrm{a}}$ Fei-Yue Gong ${ }^{\mathrm{a}}$ An Wang ${ }^{\mathrm{a}}$ Hua-Min Liang ${ }^{\mathrm{a}}$ \\ Wen-Sheng Pan ${ }^{\text {b }}$ \\ aDepartment of Gastroenterology, Zhuhai People's Hospital, Third Affiliated \\ Hospital of Jinan University College of Medicine, Zhuhai, and ${ }^{b}$ Department of \\ Gastroenterology, Second Affiliated Hospital of Zhejiang University School of \\ Medicine, Hangzhou, China
}

\section{Key Words}

Cavernous transformation of the portal vein - Liver abscess · Roux-en-Y choledochojejunostomy $\cdot$ Left hepatic lobe resection

\begin{abstract}
Cavernous transformation of the portal vein (CTPV) is not quite common in adults, and cases with CTPV and acute liver abscess are lacking. We report a patient with CTPV inducing extrahepatic and intrahepatic obstruction, finally leading to acute liver abscess due to bile duct infection. We aim to find out the possible relationship between CTPV and acute liver abscess. A 45-year-old female patient was admitted to our hospital for recurrent upper abdominal pain and distension for one year, aggravated with fever for three years. A diagnosis of CTPV and liver abscess was made by 16-slice computed tomography. Effective antibiotics and drainage were used for this patients, and she was eventually cured. When treating patients with CTPV, extrahepatic and intrahepatic obstruction, one should be aware of the presence of acute liver abscess, and empirical antibiotics might be valuable.
\end{abstract}

\section{Introduction}

Since Balfour and Stewart first reported cavernous transformation of the portal vein (CTPV) or portal cavernoma in 1869 [1], the incidence of CTPV has increased rapidly; however, the disease was not quite common in adults, mostly identified for acute upper gastrointestinal tract bleeding, obstructive jaundice, ascites and so on [2]. Zhang et al. reported that 16-slice computed tomography (CT) could diagnose CTPV noninvasively and more precisely [3]. With respect to its etiology, De Gaetano et al. found out that CTPV usually occurred in healthy livers due to development of a bypass route around the obstructed portal vein [4]. As a matter of fact, most causes are unknown. CTPV will 


\begin{tabular}{r|l|l|l}
$\begin{array}{r}\text { Case Reports in } \\
\text { Gastruenterology }\end{array}$ & $\begin{array}{l}\text { Case Rep Gastroenterol 2010;4:313-317 } \\
\text { DOI: 10.1159/000320672 }\end{array}$ & $\begin{array}{l}\text { Published online: } \\
\text { September 9, 2010 }\end{array}$ & $\begin{array}{l}\text { O 2010 S. Karger AG, Basel } \\
\text { ISSN 1662-0631 } \\
\text { www.karger.com/crg }\end{array}$ \\
\hline
\end{tabular}

eventually cause portal hypertension, jaundice, bile duct abnormalities and other related complications. Since Imoto et al. first reported a case of CTPV with acute liver abscess, limited literature has been published by Medline search [5]. Therefore, we describe a patient of CTPV with liver abscess who underwent Roux-en-Y choledochojejunostomy and left hepatic lobe resection due to calculus of the intrahepatic and extrahepatic duct.

\section{Case Report}

A 45-year-old female patient was admitted to our hospital for recurrent upper abdominal pain and distension for one year, aggravated with fever for three years. One year before, the patient had presented with upper abdominal pain to a rural clinic, and ultrasound images showed choledocholithiasis, calculus of the intrahepatic and extrahepatic duct. However, the discomfort was alleviated partially after conservative therapy. Three days earlier, upper abdominal pain, distension deteriorated with unknown causes, accompanied by high fever of $38.5^{\circ} \mathrm{C}$ without chills. Physical examination showed: temperature $38.8^{\circ} \mathrm{C}$, pulse $90 \mathrm{bpm}$, respiratory rate 23 per minute, blood pressure $125 / 70 \mathrm{~mm} \mathrm{Hg}$, an old scar with a length of $10 \mathrm{~cm}$ in right upper quadrant, epigastric tenderness. The patient underwent cholecystestomy for gallstone, left hepatic lobe resection and Roux-en-Y choledochojejunostomy for calculus of the intrahepatic duct six years before. No alcohol abuse or smoking was reported. A negative family history was found.

Blood routine showed: white blood cells (WBC) $11.2 \times 10^{9} / 1$, granulocytes $79.0 \%$, hemoglobin $66.3 \mathrm{~g} / \mathrm{l}$. Liver function test showed: alanine transaminase (ALT) $18 \mathrm{U} / \mathrm{l}$, aspartate transaminase (AST) $48 \mathrm{U} / \mathrm{l}$, AST/ALT 2.67, $\gamma$-glutamyltransferase $194 \mathrm{U} / \mathrm{l}$, alkaline phosphatase $354 \mathrm{U} / \mathrm{l}$, total bilirubin $30.5 \mu \mathrm{mol} / \mathrm{l}$, direct bilirubin $16.3 \mu \mathrm{mol} / \mathrm{l}$, indirect bilirubin $14.2 \mu \mathrm{mol} / \mathrm{l}$, albumin $28 \mathrm{~g} / \mathrm{l}, \mathrm{A} / \mathrm{G} 0.6$, C-reactive protein $127 \mathrm{mg} / \mathrm{l}$, erythrocyte sedimentation rate $90 \mathrm{~mm} / \mathrm{h}$, alpha-fetoprotein $2.2 \mathrm{ng} / \mathrm{ml}$.

Ultrasound imaging showed that there was an mixed echoic area in left hepatic lobe, approximately $7.0 \times 4.0 \mathrm{~mm}$ in size, and multiple stones were observed among the intrahepatic bile ducts. Sixteen-slice contrast-enhanced CT showed portal vein thrombosis and collateral circulation around the portal vein, dilated intrahepatic bile ducts and intrahepatic bile duct stones. Moreover, a round hypodense area was observed in left hepatic lobe (fig. 1a, b; arrows). Gastroscopy imaging showed esophegeal varices with $\mathrm{F}_{3} \mathrm{~L}_{\mathrm{s}} \mathrm{R}_{\mathrm{c}}(+) \mathrm{E}_{0}$ (fig. 1c; arrow).

\section{Results}

Besides fluid control, electrolyte and vitamin supplementation, diuretics and other conservative treatment, the patient was empirically prescribed antibiotics which could penetrate abscess tissue well: metronidazole $0.5 \mathrm{~g}$ i.v. gtt bid, piperacillin sodium and tazobactam sodium $2.5 \mathrm{~g}$ i.v. gtt bid combining with levofloxacin lactate $0.2 \mathrm{~g}$ i.v. gtt bid for one week. The patient signed informed consent and the permission was received from the local ethical committee prior to the study. Digital subtraction angiography-guided percutaneous hepatic abscess drainage was performed within one week after admission (fig. 1d). Drainage fluid culture was Pseudomonas aeruginosa. Consequently, piperacillin sodium and tazobactam sodium for injection combined with metronidazole irrigation through a drainage tube for seven days were effectively prescribed. Before discharge, blood routine indicated: WBC $4.1 \times 10^{9} / \mathrm{l}$, C-reactive protein $9 \mathrm{mg} / \mathrm{l}$, erythrocyte sedimentation rate $8 \mathrm{~mm} / \mathrm{h}$. Other inflammatory parameters had decreased to normal and there were no other syndromes or symptoms. 


\begin{tabular}{r|l|l|l} 
Case Reports in & $\begin{array}{l}\text { Case Rep Gastroenterol 2010;4:313-317 } \\
\text { DOl: 10.1159/000320672 }\end{array}$ & $\begin{array}{l}\text { Published online: } \\
\text { September 9, 2010 }\end{array}$ & $\begin{array}{l}\odot \text { ISSN 1662-0631 } \\
\text { www.karger.com/crg }\end{array}$ \\
\hline
\end{tabular}

\section{Discussion}

Khuroo et al. found that the most common cholangiographic abnormalities in portal thrombosis with biliary were irregular strictures of the extrahepatic and intrahepatic bile ducts [6]. Cholangiographic abnormalities were found in approximately $90 \%$ of patients with portal cavernoma. However, clinical manifestations of biliary obstruction occurred in only $25 \%$ of cases, and when present, they were severe and might present ascending cholangitis, acute cholecystitis, and chronic obstructive jaundice, potentially progressing to secondary biliary cirrhosis and requiring prompt treatment [7]. Chevallier et al. investigated whether extrahepatic obstruction of the portal vein contributed to the development of an extensive collateral venous network around the portal vein. Their study showed that extrahepatic obstruction of the portal vein occurred approximately 1.5 years earlier if biliary abnormalities were limited to the common bile duct and 16 years earlier if biliary abnormalities spread to the intrahepatic and common bile duct [8]. Perlemuter et al. previously postulated that biliary obstruction was possible when portal vein pressure was much higher than that of the common bile duct [9]. Dhiman et al. speculated that ischemic injury of the bile duct wall attributed to portal thrombosis [10]. Our study showed repeated onset of intrahepatic and extrahepatic calculus for many years, although the patient had undergone left hepatic lobe resection, Roux-en-Y choledochojejunostomy, and cholecystectomy; moreover, CT scan showed CTPV was certified before surgery. We presume that CTPV is a long-term course of disease which might lead to portal hypertension, acute or chronic cholangitis, intrahepatic and extrahepatic strictures and multiple stones among the bile ducts. There is a lack of definite medical strategy. Finally, bacterial liver abscess occurred due to chronic inflammation of bile ducts and pylephlebitis. The patient was cured completely with the administration of sensitive and specific antibiotics and interventional drainage therapy.

In conclusion, our case presented CTPV with severe complications, including dilated intrahepatic bile ducts and intrahepatic bile duct stones, portal hypertension and acute liver abscess. We presume that CTPV might contribute to acute liver abscess due to repeated cholangitis or strictures caused by portal cavernoma surrounding the bile ducts. Thus, preventive antibiotics may be valid. Further study will be needed due to its unknown pathogenesis. 


\begin{tabular}{r|l|l|l}
$\begin{array}{r}\text { Case Reports in } \\
\text { Gastroenterology }\end{array}$ & $\begin{array}{l}\text { Case Rep Gastroenterol 2010;4:313-317 } \\
\text { DOI: 10.1159/000320672 }\end{array}$ & $\begin{array}{l}\text { Published online: } \\
\text { September 9, 2010 }\end{array}$ & $\begin{array}{l}\text { O 2010 S. Karger AG, Basel } \\
\text { ISSN 1662-0631 } \\
\text { www.karger.com/crg }\end{array}$ \\
\hline
\end{tabular}
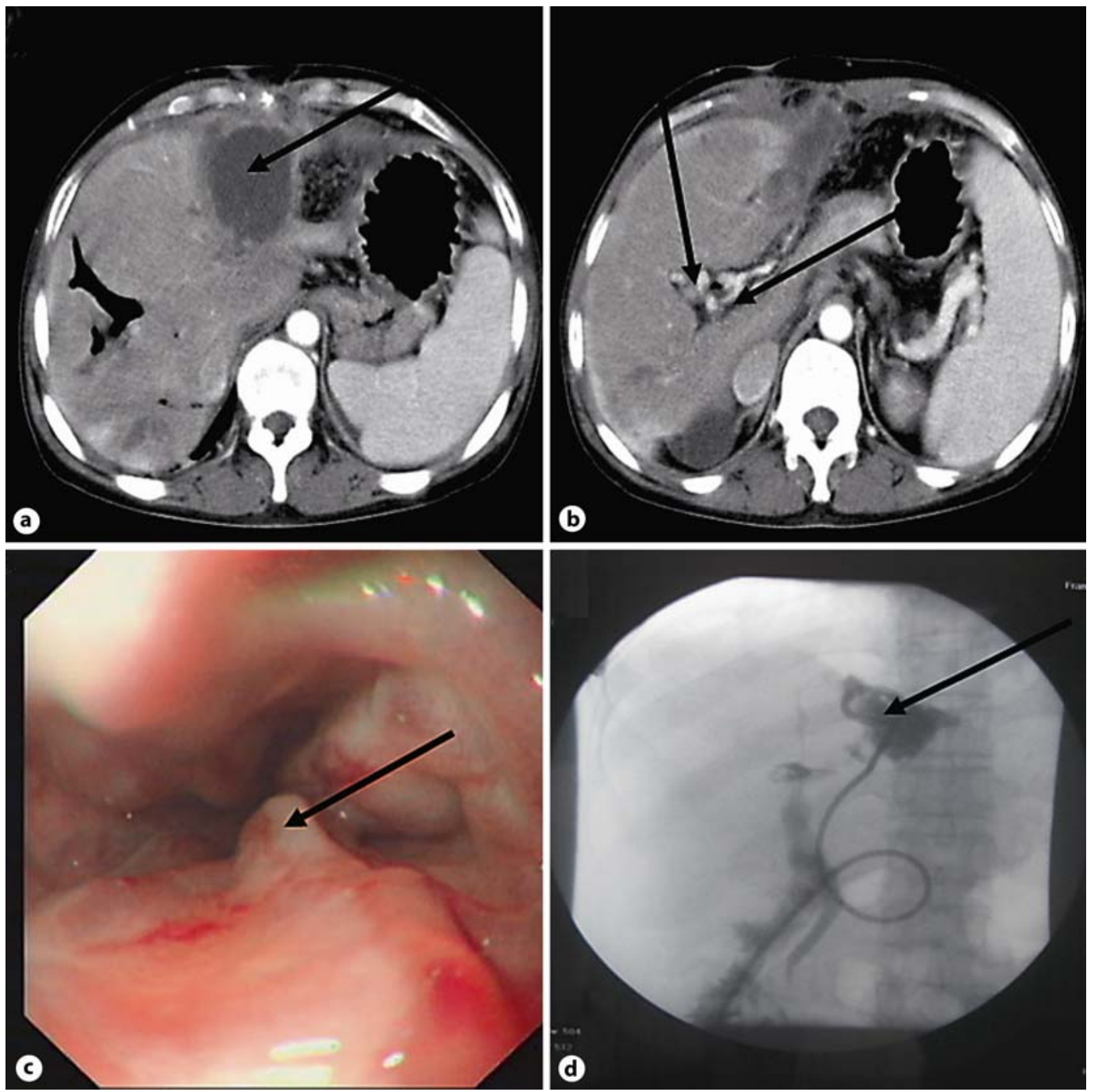

Fig. 1. A 45-year-old female patient with CTPV and drainage for acute liver abscess. a Round hypodense lesion of liver abscess (arrow). b Dilated bile ducts with multiple stones, portal vein thrombosis and collateral circulation around the portal vein (arrows). c Esophegeal varices with $\mathrm{F}_{3} \mathrm{~L}_{\mathrm{s}} \mathrm{R}_{\mathrm{c}}(+) \mathrm{E}_{0}$ (arrow). d Digital subtraction angiography-guided percutaneous hepatic abscess drainage was performed within one week after the admission (arrow).

\section{References}

1 Balfour GW, Stewart TG: Case of enlarged spleen complicated with ascites, both depending upon varicose dilation and thrombosis of the portal vein. Edinb Med J 1869;14:589-599.

2 Meredith HC, Vujic I, Schabel SI, et al: Obstructive jaundice caused by cavernous transformation of the portal vein. Br J Radiol 1978;51:1011-1012.

-3 Zhang LJ, Yang GF, Jiang B, et al: Cavernous transformation of portal vein: 16-slice CT portography and correlation with surgical procedure of orthotopic liver transplantation. Abdom Imaging 2008;33:529-535.

4 De Gaetano AM, Lafortune M, Patriquin H, et al: Cavernous transformation of portal vein: patterns of intrahepatic and splanchnic collateral circulation detected with Doppler sonography. AJR Am J Roentgenol 1995;165:1151-1155. 
5 Imoto M, Fukuda Y, Sugiyama K: A case report of cavernous transformation of the portal vein with liver abscess. Rinsho Hoshasen 1985;30:419-422.

6 Khuroo MS, Yattoo GN, Zargar SA, et al: Biliary abnormalities associated with extrahepatic portal venous obstruction. Hepatology 1993;17:807-813.

7 Condat B, Vilgrain V, Asselah T, et al: Portal cavernoma-associated cholangiopathy: a clinical and MR cholangiography coupled with MR portography imaging study. Hepatology 2003;37:1302-1308.

8 Chevallier P, Denys A, Novellas S, et al: Magnetic resonance cholangiography features of biliary abnormalities due to cavernous transformation of the portal vein. Clin Imaging 2006;30:190-194.

$\$ 9$ Perlemuter G, Béjanin H, Fritsch J, et al: Biliary obstruction caused by portal cavernoma: a study of 8 cases. J Hepatol 1996;25:58-63.

10 Dhiman RK, Puri P, Chawla Y, et al: Biliary changes in extrahepatic portal venous obstruction: compression by collaterals or ischemic? Gastrointest Endosc 1999;50:646-652. 